\title{
Field Evaluation of Imidacloprid as an Insecticidal Seed Treatment of Cotton Cultivar with Particular References to Sucking Pest, Predator and Yield
}

\author{
S.M.A. Hossain ${ }^{1}$, M.A. Baque ${ }^{2}$, M.R. Amin ${ }^{3 *}$ and I.J. Chun ${ }^{4}$ \\ ${ }^{1}$ Regional Cotton Research Station, Dinajpur, Bangladesh \\ ${ }^{2}$ Department of Zoology, Jahangirnagar University, Savar, Dhaka, Bangladesh \\ ${ }^{3}$ Department of Entomology, Hajee Mohammad Danesh Science and Technology University, Dinajpur, \\ Bangladesh \\ ${ }^{4}$ Department of Horticulture and Breeding, Andong National University, Andong, Korea \\ *E-mail: ruhul_hstu@yahoo.com
}

\begin{abstract}
Imidacloprid is a neonicotinoid insecticide that has been used for controlling sucking pests of cotton. This study showed the efficacy of the imidacloprid insecticide, Gaucho $70 \mathrm{WS}$ as seed dresser against aphids, whiteflies and thrips incidences on CB3 cotton cultivar. At the same time, inhabitants of the predators (ladybird beetles, lacewings, syrphids and spiders) and yield of the crop were evaluated. Fuzzy and delinted cotton seeds treated with imidacloprid reduced pest population compared to untreated control or foliar spray of monocrotophos $40 \mathrm{WSC}$ at $1120 \mathrm{ml} \mathrm{ha}^{-1}$, and being the highest efficacy at $5.5 \mathrm{~g} \mathrm{~kg}^{-1}$ fuzzy seed. Cotton plants grown with imidacloprid treated seeds have abundances of ladybird beetles, lacewings, syrphids and spiders. The cotton cultivar produced significantly higher yield when seeds were treated with imidacloprid at $5.5 \mathrm{~g}$ $\mathrm{kg}^{-1}$ fuzzy seed. Therefore, use of imidacloprid, Gaucho $70 \mathrm{WS}$ as a seed dresser may be an option for controlling sucking pests of cotton under field conditions.
\end{abstract}

Key words: Cotton, imidacloprid, seed treatment, pest, predator, yield.

\section{Introduction}

Cotton is the most highly valued cash crop in Bangladesh, but it appears major polluter crop because of heavy and indiscriminate pesticide use especially insecticides for controlling sucking and chewing insects. In Bangladesh, CB3 is an extensively cultivated cotton variety which has been released by the Cotton Development Board (CDB) of the country. The CB3 is a short height $(88.3 \mathrm{~cm})$ and smooth variety (Amin et al., 2008; Amin et al., 2011) and is infested by a number of sucking insects of which aphid Aphis gossypii Clover, whitefly Bemisia tabaci Gennadius and thrips Thrips tabaci Lindeman are the major destructive pests (Amin et al., 2008).

The sucking insects ingest phloem sap from the plants thus the plants reduce vigor; severe infestations destroy terminal buds and infested plants produce excessive branching (Bohmfalk et al., 1996). The aphid and whitefly secrete honeydew on cotton lint which creates problem during lint processing at textile mills (Bellows et al., 
1994; Bohmfalk et al., 1996; Bi et al., 2001). Moreover, the deposition of honeydew droplets on leaves provide a suitable substrate for sooty mold development, which inhibits foliar photosynthesis and reduces yield and quality (Bohmfalk et al., 1996; Bi et al., 2001). The predators associated with cotton pests include beetles, true bugs, lacewings, flies, midges, spiders, wasps, and predatory mites (Hoffmann and Frodsahm, 1993). The most abundant predatory inhabitants in the cotton field of Bangladesh are ladybird beetles, syrphids, lacewings and spiders (Azad et al., 2010).

Proper variety selection and protection of crops from pests and diseases are important prerequisites for higher yield and quality of cotton. Cotton growers of Bangladesh spray insecticides throughout the season to protect their crops. Foliar applications of insecticides create complications in the ecosystem and reduce predator and insect pollinator species (Moser and Obrycki, 2009). The residues of the foliar applications of imidacloprid killed foraging predators and parasitoids (Boyd and Boethel, 1998; Sclar et al., 1998). On the contrary, seed treatment with systemic insecticide is a less pollution, environment friendly, cost-cutting, selective and least interference to natural equilibrium in integrated pest management programmes (Taylor et al., 2001; Nault et al., 2004).

Imidacloprid is a neonicotinoid insecticide in the chloronicotinyl nitroguanidine chemical family. This chemical is most promising, low cost, selective and less polluting and has been widely used as seed dresser for management of cotton pests (Udikeri et al., 2007).
Vastrad (2003) reported that imidacloprid insecticide as seed dresser has proved effective against pest abundance. Imidacloprid has appeared the best seed dresser in cotton and has been found to be promising against cotton sucking pests (Patil et al., 1999; Dandale et al., 2001; Vadodaria et. al., 2001; Dhawan and Simwat, 2002; Patil et al., 2004). This compound keeps cotton crop free from infestation of sucking pests for at least 45 days after sowing and also comparatively safe to natural enemies (Udikeri et al., 2007).

Imidacloprid as seed treatment agent moves systemically within the plant and provide protection against piercing-sucking insects (Zhang et al., 2011). Now-a-days, the cotton growers of Bangladesh are showing interest on seed dressing for protecting their crops from pest attack (Amin et al., 2009). The effectiveness of imidacloprid treated cotton seeds relation with the population density of sucking pests, predators and yield under Bangladesh condition are unknown. In the present study imidacloprid insecticide, Gaucho 70 WS was used as seed dresser of CB3 cotton cultivar and investigation was done to know its effect on the abundance of sucking pests, predators and yield under field condition.

\section{Materials and methods}

\section{Seed deliting}

CB3 cotton seeds were delinted by a delinting machine (Bajaj Steel Industries Ltd., Nagpur, Maharashtra, India). Seeds were fed into the stainless steel container of the machine and the agitator of the machine was then rotated and commercial sulphuric 
acid was poured slowly into the container at $100 \mathrm{ml} \mathrm{kg}^{-1}$ seed having the cotton seeds through its periphery. Due to the churning action, the fuzz was uniformly subjected to the acid reaction. At the end of 90 seconds, the acid treated seeds were washed with water. The process of washing with water was repeated three times and then the seeds were collected and dried.

\section{Seed treatment}

Fuzzy and delinted seeds were separately soaked in water for half an hour and then put on sieves to dry. Therefore, imidacloprid (Gaucho 70 WS powder) and seeds were poured into different bowls following 1.5, $2.5,3.5,4.5$ or $5.5 \mathrm{~g} \mathrm{~kg}^{-1}$ seed and stirred for 10-15 minutes for complete adherence of the chemical to the individual seed coat. Then the seeds were put on papers and dried in the sun for 30-40 minutes, therefore, stored in brown paper bags until sowing.

\section{Cultivation of crops}

The crops were cultivated during three consecutive seasons of 2008, 2009 and 2010 at the Regional Cotton Research Station, Dinajpur $\left(25^{\circ} 13^{\prime} \mathrm{N}, 88^{\circ} 23^{\prime} \mathrm{E}\right)$ in Bangladesh. The experiments were conducted with fuzzy and delinted seeds of CB3 cotton cultivar and treatments consisted of untreated controls and seeds treated with imidacloprid insecticide Gaucho $70 \mathrm{WS}$ at 1.5, 2.5, 3.5, 4.5 or $5.5 \mathrm{~g} \mathrm{~kg}^{-1}$ seed. An additional treatment was made with foliar spray of monocrotophos $40 \mathrm{WSC}$ at $1120 \mathrm{ml} \mathrm{ha}^{-1}$ for four times, which is widely used by the cotton growers of Bangladesh. The experimental design was a randomized complete block with three replications. The plot size was $5.4 \mathrm{~m} \times 5.0 \mathrm{~m}$ and the spacing between block to block and plot to plot was $1.5 \mathrm{~m}$ and $1.0 \mathrm{~m}$, respectively. Seeds were sown in rows with $45 \mathrm{~cm}$ apart and row to row distance was $90 \mathrm{~cm}$. Fertilization and intercultural operations were maintained according to the recommendations of the Cotton Development Board of Bangladesh.

\section{Observation of sucking pests and predator populations}

After emergence of seedlings, field inspection was done fortnightly intervals up to 70 days for observation of the population of sucking pests, viz. aphid (A. gossypii), whitefly (B. tabaci) and thrips (T. tabaci). Every inspection, five plants were randomly selected from each plot and the number of sucking pests on the top, middle and bottom leaf were counted. Similarly, adult predators viz. ladybird beetle Coccinella septempunctata L. and Menochilus sexmaculatus Fabricius, lacewing Chrysoperla carnea Stephens, syrphid Syrphus opinator Sacken and spider Chiracanthium inclusum Hentz and Lycosa pseudoannulata Bosenberg and Strand populations were recorded.

\section{Measurement of cotton yield}

Open bolls (seed cotton) in each plot were handpicked and obtained seed cotton yield of each treatment was converted into ton ha 1 .

\section{Data analysis}

The data on mean population of sucking pests, predators, and seed cotton yield of the year 2008, 2009 and 2010 were calculated and subjected to statistical analyses using analysis of variance (ANOVA), and the mean comparisons were made by Duncan's Multiple Range Test (DMRT). 
S.M.A. Hossain, M.A. Baque, M.R. Amin and I.J. Chun / Our Nature (2012) 10: 44-52

\section{Results}

The efficacy of imidacloprid seed treatment against sucking pest incidence on CB3 cotton cultivar under field condition is presented in table 1 . The imidacloprid seed treatments showed significantly lower incidence of aphid on treatment groups than those on the untreated control $\left(\mathrm{F}_{11,96}=29.3\right.$, $\mathrm{p}<0.001)$. The efficacy of the seed treatments showed that aphid incidence on CB3 decreased from 5.1 to 0.8 and seed treatment was most effective against aphid when imidacloprid was applied at $5.5 \mathrm{~g} \mathrm{~kg}^{-1}$ fuzzy seed.

Table 1 shows that the whitefly population on CB3 cultivar varied from 1.8 to 9.3 and the results showed that whitefly population on the treatment groups were significantly lower than those on the untreated control $\left(\mathrm{F}_{11,96}=11.5, \mathrm{p}<0.001\right)$. The cultivar exerted significantly lowest incidence of whitefly when seed treatment was done with Gaucho 70 WS at $5.5 \mathrm{~g} \mathrm{~kg}^{-1}$ fuzzy seed. The incidence of thrips on cotton cultivar was found significantly lower in the treatments than those on the untreated control $\left(\mathrm{F}_{11,96}=34.9, \mathrm{p}<0.001\right)$. The number of thrips on cotton cultivar ranged from 2.2 to 10.9 and the plants showed significantly lowest incidence in the treatment imidacloprid at $5.5 \mathrm{~g} \mathrm{~kg}^{-1}$ fuzzy seed.

The ladybird beetle, lacewing, syrphid and spider populations associated with CB3 cultivar are presented in table 2 . Imidacloprid seed treatments significantly reduced lady beetles population on treatment groups compared to control $\left(\mathrm{F}_{11,96}\right.$ $=77.7, \mathrm{p}<0.001)$. Lady beetles population on studied cotton cultivar was found lowest (2.1 leaf $\left.{ }^{-1}\right)$ when seed treatment was done with Gaucho 70 WS at $5.5 \mathrm{~g} \mathrm{~kg}^{-1}$ fuzzy seed. The lacewing inhabitants on CB3 cotton cultivar varied from 1.6 to 5.9 leaf $^{-1}$ and the results differed significantly $\left(\mathrm{F}_{11,96}=56.5, \mathrm{p}\right.$ $<0.001)$. The treatment Gaucho $70 \mathrm{WS}$ at $5.5 \mathrm{~g} \mathrm{~kg}^{-1}$ fuzzy seed revealed the lowest abundance of lacewing on the cultivar. The syrphid population on CB3 was observed 1.5 to 5.2 leaf $^{-1}$, and there were significant differences among the treatments $\left(\mathrm{F}_{11,96}=\right.$ 53.8, $\mathrm{p}<0.001)$. Imidacloprid seed treatments significantly suppressed spider population on CB3 cotton cultivar $\left(\mathrm{F}_{11,96}=\right.$ $41.5, \mathrm{p}<0.001)$ and spider population on the cultivar ranged from 1.4 to 5.6 leaf $^{-1}$. The treatment Gaucho $70 \mathrm{WS}$ at $5.5 \mathrm{~g} \mathrm{~kg}^{-1}$ fuzzy seed showed the lowest abundance of syrphid and spider on the cultivar.

Table 3 shows that seed yield of CB3 cultivar varied from 0.40 to $1.43 \mathrm{t} \mathrm{ha}^{-1}$ and the results differed to a significant level $\left(\mathrm{F}_{11}\right.$, $\left.{ }_{96}=170.4, \mathrm{p}<0.001\right)$. Among the treatments, Gaucho 70 WS at $5.5 \mathrm{~g} \mathrm{~kg}^{-1}$ fuzzy seed revealed the highest seed yield (Table 3).

\section{Discussion}

Seed treatment is a highly progressive and demandable technology for management of various crop pests (Taylor et al., 2001; Magalhaes et al., 2009). This study showed that imidacloprid seed treatments effectively reduced aphid, whitefly and thrips inhabitants in the cotton field of Bangladesh. Both fuzzy and delinted seeds exhibited higher efficacy against the sucking pests in the field conditions. This was consistence with Zhang et al. (2011), who reported that imidacloprid seed treatments were effective in suppressing the whitefly population in cotton fields. Our 
S.M.A. Hossain, M.A. Baque, M.R. Amin and I.J. Chun / Our Nature (2012) 10: 44-52

Table 1. Incidence of sucking pests on CB3 cotton cultivar as influenced by seed treatment with imidacloprid Gaucho 70WS

\begin{tabular}{lccc}
\hline Treatments & Aphid & $\begin{array}{c}\text { Number of pests (mean } \pm \text { SD)/plant } \\
\text { Whitefly }\end{array}$ & Thrips \\
\hline Gaucho $1.5 \mathrm{~g} \mathrm{~kg}^{1}$ fuzzy seed & $1.6 \pm 0.2 \mathrm{~b}$ & $4.3 \pm 2.0 \mathrm{~b}$ & $4.7 \pm 1.1 \mathrm{bc}$ \\
Gaucho $2.5 \mathrm{~g} \mathrm{~kg}^{-1}$ fuzzy seed & $1.4 \pm 0.3 \mathrm{bd}$ & $3.5 \pm 1.7 \mathrm{bd}$ & $4.1 \pm 1.0 \mathrm{bd}$ \\
Gaucho $3.5 \mathrm{~g} \mathrm{~kg}^{-1}$ fuzzy seed & $1.2 \pm 0.3 \mathrm{bd}$ & $3.1 \pm 1.7 \mathrm{bd}$ & $3.4 \pm 0.8 \mathrm{dg}$ \\
Gaucho $4.5 \mathrm{~g} \mathrm{~kg}^{-1}$ fuzzy seed & $1.0 \pm 0.3 \mathrm{bd}$ & $2.4 \pm 1.2 \mathrm{bd}$ & $2.8 \pm 0.7 \mathrm{eg}$ \\
Gaucho $5.5 \mathrm{~g} \mathrm{~kg}^{-1}$ fuzzy seed & $0.8 \pm 0.3 \mathrm{~d}$ & $1.8 \pm 0.9 \mathrm{~d}$ & $2.2 \pm 0.7 \mathrm{~g}$ \\
Gaucho $1.5 \mathrm{~g} \mathrm{~kg}^{1}$ delinted seed & $1.7 \pm 0.2 \mathrm{~b}$ & $4.1 \pm 1.7 \mathrm{~b}$ & $5.2 \pm 1.5 \mathrm{~b}$ \\
Gaucho 2.5 g kg delinted seed & $1.5 \pm 0.3 \mathrm{bd}$ & $3.2 \pm 1.5 \mathrm{bd}$ & $4.5 \pm 1.3 \mathrm{bd}$ \\
Gaucho $3.5 \mathrm{~g} \mathrm{~kg}^{-1}$ delinted seed & $1.3 \pm 0.3 \mathrm{bd}$ & $2.8 \pm 1.3 \mathrm{bd}$ & $3.9 \pm 1.1 \mathrm{ce}$ \\
Gaucho $4.5 \mathrm{~g} \mathrm{~kg}^{-1}$ delinted seed & $1.2 \pm 0.4 \mathrm{bd}$ & $2.2 \pm 1.0 \mathrm{~cd}$ & $3.5 \pm 1.4 \mathrm{cf}$ \\
Gaucho 5.5 g kg delinted seed & $0.9 \pm 0.3 \mathrm{~cd}$ & $2.1 \pm 0.7 \mathrm{~cd}$ & $2.6 \pm 0.8 \mathrm{fg}$ \\
Monocrotophos 1120 ml ha-1 & $1.5 \pm 0.2 \mathrm{bc}$ & $3.9 \pm 2.2 \mathrm{bc}$ & $4.5 \pm 1.3 \mathrm{bd}$ \\
Control (fuzzy seed) & $5.3 \pm 1.9 \mathrm{a}$ & $9.3 \pm 3.4 \mathrm{a}$ & $11.1 \pm 0.9 \mathrm{a}$ \\
\hline
\end{tabular}

Table 2. Abundance of major predators on CB3 cotton cultivars as influenced by seed treatment with imidacloprid Gaucho 70WS

\begin{tabular}{lcccc}
\hline Treatments & \multicolumn{3}{c}{ Number of predators (mean \pm SD)/plant } \\
& Ladybird beetle & Lacewing & Syrphid & Spider \\
\hline Gaucho $1.5 \mathrm{~g} \mathrm{~kg}^{1}$ fuzzy seed & $4.5 \pm 0.4 \mathrm{c}$ & $3.8 \pm 0.5 \mathrm{c}$ & $3.6 \pm 0.4 \mathrm{f}$ & $3.6 \pm 0.3 \mathrm{bc}$ \\
Gaucho $2.5 \mathrm{~g} \mathrm{~kg}^{-1}$ fuzzy seed & $3.9 \pm 0.4 \mathrm{~d}$ & $3.1 \pm 0.5 \mathrm{~d} \mathrm{e}$ & $2.9 \pm 0.4 \mathrm{~d}$ & $2.9 \pm 0.3 \mathrm{de}$ \\
Gaucho $3.5 \mathrm{~g} \mathrm{~kg}^{-1}$ fuzzy seed & $3.1 \pm 0.4 \mathrm{ef}$ & $2.6 \pm 0.3 \mathrm{fg}$ & $2.5 \pm 0.5 \mathrm{ef}$ & $2.4 \pm 0.1 \mathrm{fg}$ \\
Gaucho $4.5 \mathrm{~g} \mathrm{~kg}^{-1}$ fuzzy seed & $2.6 \pm 0.3 \mathrm{~g}$ & $2.3 \pm 0.4 \mathrm{~g}$ & $2.0 \pm 0.3 \mathrm{~g}$ & $1.9 \pm 0.3 \mathrm{~g}$ \\
Gaucho $5.5 \mathrm{~g} \mathrm{~kg}^{-1}$ fuzzy seed & $2.1 \pm 0.3 \mathrm{~h}$ & $1.6 \pm 0.3 \mathrm{~h}$ & $1.5 \pm 0.3 \mathrm{~h}$ & $1.4 \pm 0.3 \mathrm{~h}$ \\
Gaucho $1.5 \mathrm{~g} \mathrm{~kg}^{1}$ delinted & $5.2 \pm 0.3 \mathrm{~b}$ & $4.6 \pm 0.5 \mathrm{~b}$ & $4.2 \pm 0.3 \mathrm{~b}$ & $4.0 \pm 1.0 \mathrm{bc}$ \\
seed & $4.8 \pm 0.6 \mathrm{c}$ & $3.9 \pm 0.6 \mathrm{c}$ & $3.6 \pm 0.5 \mathrm{c}$ & $3.6 \pm 0.4 \mathrm{bc}$ \\
Gaucho $2.5 \mathrm{~g} \mathrm{~kg}^{-1}$ delinted & $3.9 \pm 0.4 \mathrm{~d}$ & $3.5 \pm 0.5 \mathrm{~cd}$ & $3.1 \pm 0.2 \mathrm{~d}$ & $3.1 \pm 0.1 \mathrm{~cd}$ \\
seed & & & & \\
Gaucho $3.5 \mathrm{~g} \mathrm{~kg}^{-1}$ delinted & $3.5 \pm 0.4 \mathrm{e}$ & $3.1 \pm 0.2 \mathrm{de}$ & $2.9 \pm 0.3 \mathrm{de}$ & $2.8 \pm 0.2 \mathrm{df}$ \\
seed & & & \\
Gaucho $4.5 \mathrm{~g} \mathrm{~kg}^{-1}$ delinted & $2.9 \pm 0.3 \mathrm{f} \mathrm{g}$ & $2.7 \pm 0.2 \mathrm{eg}$ & $2.4 \pm 0.2 \mathrm{f}$ & $2.4 \pm 0.4 \mathrm{ef}$ \\
seed & & & \\
Gaucho $5.5 \mathrm{~g} \mathrm{~kg}^{-1}$ delinted & $3.1 \pm 0.3 \mathrm{ef}$ & $2.9 \pm 0.4 \mathrm{ef}$ & $2.8 \pm 0.4 \mathrm{df}$ & $2.9 \pm 0.4 \mathrm{de}$ \\
seed & $6.5 \pm 0.8 \mathrm{a}$ & $5.9 \pm 0.8 \mathrm{a}$ & $5.2 \pm 0.8 \mathrm{a}$ & $5.6 \pm 0.9 \mathrm{a}$ \\
Monocrotophos 1120 ml ha & & & \\
Control (fuzzy seed) & &
\end{tabular}

Table 3. Yield (seed cotton) of CB3 cotton cultivar as influenced by seed treatment with imidacloprid Gaucho 70WS

\begin{tabular}{lc}
\hline Treatment & Yield (t/ha) \\
\hline Gaucho $1.5 \mathrm{~g} \mathrm{~kg}^{1}$ fuzzy seed & $0.84 \pm 0.04 \mathrm{fg}$ \\
Gaucho $2.5 \mathrm{~g} \mathrm{~kg}^{-1}$ fuzzy seed & $0.94 \pm 0.07 \mathrm{e}$
\end{tabular}


S.M.A. Hossain, M.A. Baque, M.R. Amin and I.J. Chun / Our Nature (2012) 10: 44-52

\begin{tabular}{lc} 
Gaucho $3.5 \mathrm{~g} \mathrm{~kg}^{-1}$ fuzzy seed & $1.10 \pm 0.05 \mathrm{~d}$ \\
Gaucho $4.5 \mathrm{~g} \mathrm{~kg}^{-1}$ fuzzy seed & $1.27 \pm 0.05 \mathrm{~b}$ \\
Gaucho $5.5 \mathrm{~g} \mathrm{~kg}^{-1}$ fuzzy seed & $1.43 \pm 0.11 \mathrm{a}$ \\
Gaucho $1.5 \mathrm{~g} \mathrm{~kg}^{1}$ delinted seed & $0.78 \pm 0.04 \mathrm{~g}$ \\
Gaucho $2.5 \mathrm{~g} \mathrm{~kg}^{-1}$ delinted seed & $0.88 \pm 0.06 \mathrm{ef}$ \\
Gaucho $3.5 \mathrm{~g} \mathrm{~kg}^{-1}$ delinted seed & $0.88 \pm 0.06 \mathrm{ef}$ \\
Gaucho $4.5 \mathrm{~g} \mathrm{~kg}^{-1}$ delinted seed & $1.20 \pm 0.07 \mathrm{c}$ \\
Gaucho $5.5 \mathrm{~g} \mathrm{~kg}^{-1}$ delinted seed & $1.27 \pm 0.05 \mathrm{~b}$ \\
Monocrotophos $1120 \mathrm{ml} \mathrm{ha}^{-1}$ & $0.94 \pm 0.06 \mathrm{e}$ \\
Control (fuzzy seed) & $0.40 \pm 0.07 \mathrm{~h}$ \\
\hline Means followed by same letter(s) are not significantly different (DMRT, $\mathrm{p} \leq 0.05)$ \\
\hline
\end{tabular}

findings also agree with the results of Mote et al. (1995) and Patil et al. (2003), who observed that seed treatment with inidacloprid reduced the sucking pest population below the economic threshold level up to 40 days after sowing. There is report that seed treatment of cotton with imidacloprid was effective against leafhopper population up to 61 days after germination (Dandale et al., 2001; Murugan et al., 2003).

This study showed that imidacloprid seed treatments had proved better performances compared to control as well as traditional pest control method (foliar application of monocrotophos at $1120 \mathrm{ml}$ $\mathrm{ha}^{-1}$ ). This study also showed that sucking pest population on CB3 cultivar differed regarding to the dosages of seed treatment. The cultivar showed lower pest incidence when the fuzzy and delinted seeds were treated with imidacloprid at $5.5 \mathrm{~g} \mathrm{~kg}^{-1}$ seed. Our results also showed that pest incidence decreased with increasing doses of Gaucho 70 WS.

Imidacloprid is a broad-spectrum insecticide that kills most insect species (Lind et al., 1998a; 1998b). Our study showed that imidacloprid seed treatments were safer for CB3 cultivar but reduced predator population in the field. It is revealed that ladybird beetles, lacewings, syrphids and spiders were abundant on CB3 cotton plants that were grown from the seeds treated with imidacloprid. Imidacloprid seed treatments in higher concentration exhibit translocation to flowers and reduce survivorship and alter behavior of pink ladybird beetle, Coleomegilla maculate DeGeer and green lacewing, Chrysoperla carnea Stephens (Rogers et al., 2007). The present study showed that predator abundances on the cultivar were positively correlated with the abundances of prey. Zhang et al. (2011) reported that all leaves of the cotton plants at 40 day after germination contained low concentrations of the active ingredients of the imidacloprid insecticides. Early research also showed that concentrations of imidacloprid in plants gradually reduced from bottom to top leaves and most of the translocated imidacloprid exist in the cotyledon (Tröltzsch et al., 1994).

Mote et al. (1995) reported that imidacloprid seed treatment increased nitrogen and chlorophyll content in cotton plants thus the plants enhance vigor and 
growth. This study shows that imidacloprid treatment kept the cotton plants free from severe insect infestation, thus normal vigor of the plants were not hampered and produced higher yield compared to untreated control. This finding shows concur with Udikeri et al. (2007), who obtained higher seed yield of cotton by protecting the crop from early sucking pest infestation by treating the seeds with Chlothianidin $600 \mathrm{FS}$ (Poncho) at $9.0 \mathrm{ml} \mathrm{kg}$ ${ }^{1}$ seed. Dobbs et al. (2006) reported that imidacloprid (Gaucho) seed treatments produced significantly higher lint yield of cotton than untreated control.

Integrated pest management (IPM) programmes include biological control, biorational insecticides and conventional insecticides for controlling pests, and cultivation of resistant varieties. Imidacloprid is effective for controlling sucking and piercing insects of cotton, in addition, there have been anecdotal reports of yield and growth enhancement after multiple foliar applications (Gonias et al. 2003). Under African condition, seed treatment with this chemical was proved significant effective against sucking pests (Salmon, 2003). Imidacloprid as seed treatment agent move systemically within the plant and provide protection against pests. This chemical has been used successfully for the control of early pest complex in sugar beet, maize, vegetables and other crops (Altmann, 1991; Elbert et al. 2008; Taylor et al. 2001). The present investigation clearly suggest that imidacloprid seed dresser offers promising protection against aphid, whitefly and thrips on $\mathrm{CB} 3$ cotton cultivar without disrupting natural enemy complex which suppressed subsequent resurgence and secondary pest outbreak. Thus seed treatment of CB3 cotton cultivar with imidacloprid can be an ideal strategy for IPM in the cotton field of Bangladesh.

\section{References}

Altmann, R. 1991. Gaucho-ein neues Insektizid zur Bekämpfung von Rübenschadlingen. Planzenschutz-Nachrichten Bayer. 44: 159-174.

Amin, M.R., M,A. Ahad, M.H. Hossain, S.M.A. Hossain and D.A. Tithi 2008. Characteristics of some cotton varieties in relation to seasonal abundance of pests, predators and their impact on yield and quality. J. Agrofor. Environ. 2: 67-70.

Amin, M.R., D.A. Tithi and Y.J. Kwon 2011. Characteristics of three cotton varieties and their impact on feeding and growth of cotton armyworm. Ent. Res. 41: 151-156.

Amin, M.R., D.A. Tithi, H.M.S. Azad and S.M.A. Hossain 2009. Management of cotton pests using seed treating insecticide and pyrethroids at different locations of Bangladesh. J. Sci. Technol. (Dinajpur). 7: 123-128.

Azad, H.M.S., M.R. Amin, S.M.A Hossain and D.A. Tithi 2010. Field abundance and incidence of predator associated with different cotton varieties at Dinajpur in Bangladesh. J. Environ. Sci. Natural Resources. 3: 127-130.

Bellows, T.S., T.M.Jr. Perring, R.J. Gill and D.H. Headrick 1994. Description of a species of Bemisia tabaci (Homoptera: Aleyrodidae). Ann. Entomol. Soc. Am. 87: 195-2006.

Bi, J.L., G.R. Ballmer, D.L. Hendrix, T.J. Henneberry and N.C. Toscano 2001. Effect of cotton nitrogenfertilizer on Bemisia argentifolii populations and honeydew production. Entomol. Exp. Appl. 99: 25-36.

Bohmfalk, G.T., R.E. Frisbie, W.L. Sterling, R.B. Metzer and A.E. Knutson 1996. Identification, biology and sampling of cotton insects. Texas Agril Exten Serv, The Texas A \& M Univ. System.

Boyd, M.L. and K.J. Boethel 1998. Residual toxicity of selected insecticides to heteropteran predacious species (Heteroptera: Lygaeidae, Nabidae, Pentatomidae) on soybean. Environ. Entomol. 27: 154-160.

Dandale, H.G., A.Y. Thakare, S.N. Tikar, N.G.V. Rao and S.A. Nimblakar 2001. Effect of seed treatment 
S.M.A. Hossain, M.A. Baque, M.R. Amin and I.J. Chun / Our Nature (2012) 10: 44-52

on sucking pests of cotton and yield of seed cotton. Pestology. 25: 20-23.

Dhawan, A.K. and G.S. Simwat 2002. Field evaluation of thiamethoxam for control of cotton jassid Amrasca biguttula buguttula (Ishida) on upland cotton. Pestology. 26: 15-19.

Dobbs, R.R., N.W. Buehring, J.T. Reed and M.P. Harrison 2006. Thrips control response to Temik and Gaucho in UNR cotton. Res. Report 2006, Mississippi Agril. Forest Exp. Station, Mississippi State Univ. USA. 23: 1-3.

Elbert, A, M. Haas, B. Springer, W. Thielert and R. Nauen 2008. Applied aspects of neonicotinoid uses in crop protection. Pest Manag. Sci. 64: 1099-1105.

Gonias, E.D., D.M. Oosterhuis, A.C. Bibi and R.S. Brown 2003. Yield, growth and physiology of Trimaxt ${ }^{M}$ treated cotton. Summaries of Arkansas Cotton Res. 2003, Univ. Arkansas, USA, pp. 139144.

Hoffmann, M.P. and A.C. Frodsahm 1993. Natural enemies of vegetable insect pests. Cooperative Extension, Cornell Univ., Ithaca, NY, p. 63.

Lind, R.J., M.S. Clough, F.G.P. Earley 1998a. Wonnacott S and Reynolds SE, Characterization of the relationship between binding sites for imidacloprid and other nicotinic ligands in insects. Pest Sci. 55: 1029-1031.

Lind, R.J., M.S. Clough, S.E. Reynolds and F.G.P. Earley 1998b. Imidacloprid lebels high- and low affinity nicotinic acetylcholine receptor - like binding sites in the aphid Myzus persicae (Hemiptera: Aphididae). Pestic. Biochem. Physiol. 62: 3-14.

Magalhaes, L.C., T.E. Hunt and B.D. Siegfried 2009. Efficacy of neonicotinoid seed treatments to reduce soybean aphid populations under field and controlled conditions in Nebraska. J. Econ. Entomol. 102: 187-195.

Moser, S.E. and J.J. Obrycki 2009. Non-target effects of neonicotinoid seed treatments; mortality of coccinellid larvae related to zoophytophagy. Biol. Cont. 51: 487-492.

Mote, U.N., R.V. Datkile and G.R. Loage 1995. Efficacy of imidacloprid as seed treatment against initial sucking pests of cotton. Pestology. 19: 5-8.

Murugan, M., N. Sathiah, N. Dhandapani, R.J. Rabindra and S. Mohan 2003. Laboratory assays on the role of Indian transgenic Bt cotton in the management of Helicoverpa armigera (Hubner)
(Noctuidae: Lepidoptera). Indian J. Plant Protection. 31: 1-5.

Nault, B.A., A.G. Taylor, M. Urwiler, T. Rabaey and W.D. Hutchison 2004. Neonicotiniod seed treatments for managing potato leafhopper infestations in snap bean. Crop Protection. 23: 147-154.

Patil, B.C., S.B. Patil, S.S. Vdikeri and B.M. Khadi 2003. Effect of imidacloprid seed treatment on growth, yield, seedling vigor and biophysical parameters in cotton (Gossypium spp) genotypes, Proc. World Cotton Res. Conf. 3, Cape Town, South Africa, 9-13 March 2003, ed. by Swanepoel A, Pretoria, South Africa.

Patil, B.V., A.G. Sreenivas, M.S. Rehaman and M. Bheemanna 1999. Imidacloprid 70 WS seed treatment against early cotton sucking pest. Pestology. 23: 35-39.

Patil, S.B, S.S. Udikeri and B.M. Khadi 2004 Thiamethoxam 35 FS - A new seed dresser formulation for sucking pest control in cotton crop. Pestology. 28: 34-37.

Rogers, M.A., V.A. Krischik and L.A. Martin 2007. Effects of soil application of imidacloprid on survival of adult green lacewing, Chrysoperla carnea (Neuroptera: Chrysopidae), used for biological control in greenhouses. Biol. Control. 42: 172-177.

Salmon, E. 2003. Gaucho - an innovation in cotton seed treatment under African conditions, Proc. World Cotton Res. Conf. 3, Cape Town, South Africa, 9-13 March 2003, ed. by Swanepoel A, Pretoria, South Africa.

Sclar, D.C., D. Gerace and W.S. Cranshaw 1998 Observations of population increases and injury by spider mites (Acari: Tetranychidae) on ornamental plants. J. Econ. Entomol. 91: 250-255.

Smith, S.F. and V.A. Krischik 1999. Effects of systemic imidacloprid on Coleomegilla maculata (Coleoptera: Coccinellidae). Environ. Entomol. 28: 1189-1195.

Taylor, A.G., C.J. Eckenrode and R.W. Straub 2001. Seed coating technologies and treatments for onions: challenges and progress. HortSci. 36: 199205.

Tröltzsch, C.M., F. Führ, J. Wieneke and A. Elbert 1994. Influence of various irrigation producers on the uptake of imidacloprid by cotton after seed treatment. Pflanzenschutz-Nachrichten Bayer. 47: 241-291. 
S.M.A. Hossain, M.A. Baque, M.R. Amin and I.J. Chun / Our Nature (2012) 10: 44-52

Udikeri, S.S., S.B. Patil, L.K. Naik, V. Rachappa, F. Nimbal and G.S. Guruprasad 2007. Poncho 600 FS - A new seed dressing formulation for sucking pest management in cotton. Karnataka J. Agric. Sci. 20: 51-53.

Vadodaria, M.P., U.G. Patel, C.J. Patel, R.B. Patel and I.M. Maisuria 2001. Thiamethoxam (Cruiser) 70 WS: A new seed dresser against sucking pests of cotton. Pestology. 25: 13-18.
Vastrad, A.S. 2003. Neonicotinoids - Current success and future outlook. Pestology 27: 60-63.

Zhang, L., S.M. Greenberg, Y. Zhang and T. Liu 2011. Effectiveness of thiamethoxam and imidacloprid seed treatments against Bemisia tabaci (Hemiptera: Aleyrodidae) on cotton. Pest Manag. Sci.67:226-232. 